\title{
Role of voltage-gated calcium channels in epilepsy
}

\author{
Gerald W. Zamponi ${ }^{1}$, Philippe Lory ${ }^{2}$, and Edward Perez-Reyes ${ }^{3}$ \\ ${ }^{1}$ Department of Physiology and Pharmacology, Hotchkiss Brain Institute, University of Calgary, \\ Calgary, T2N 4N1, Canada \\ ²Département de Physiologie, Institut de Génomique Fonctionnelle, CNRS UMR 5203, INSERM \\ U661, Université de Montpellier 1 et 2, 34094 Montpellier, France \\ ${ }^{3}$ Department of Pharmacology and Neuroscience Graduate Program, University of Virginia, \\ Charlottesville, Virginia 22908, U.S.A
}

\begin{abstract}
It is well established that idiopathic generalized epilepsies (IGEs) show a polygenic origin and may arise from dysfunction of various types of voltage- and ligand-gated ion channels. There is an increasing body of literature implicating both high and low voltage-activated (HVA and LVA) calcium channels and their ancillary subunits in IGEs. $\mathrm{Ca}_{\mathrm{v}} 2.1$ (P/Q-type) calcium channels control synaptic transmission at presynaptic nerve terminals, and mutations in the gene encoding the $\mathrm{Ca}_{\mathrm{v}} 2.1 \alpha 1$ subunit (CACNA1A) have been linked to absence seizures in both humans and rodents. Similarly, mutations and loss of function mutations in ancillary HVA calcium channel subunits known to coassemble with $\mathrm{Ca}_{\mathrm{v}} 2.1$ result in IGE phenotypes in mice. It is important to note that in all these mouse models with mutations in HVA subunits there is a compensatory increase in thalamic LVA currents, which likely leads to the seizure phenotype. In fact, gain of function mutations have been identified in $\mathrm{Ca}_{\mathrm{v}} 3.2$ (an LVA or T-type calcium channel encoded by the CACNAIH gene) in patients with congenital forms of IGEs, consistent with increased excitability of neurons as a result of enhanced T-type channel function. Here we provide a broad overview of the roles of voltage-gated calcium channels, their mutations, and how they might contribute to the river that terminates in epilepsy.
\end{abstract}

\section{Keywords}

calcium channel; P/Q-type channels; T-type channels; epilepsy; seizures

\section{Introduction}

Epilepsy is a disorder that results from abnormal hyperexcitable and hypersynchronous activity of neurons [28]. Epileptic seizures can have a wide variety of origins, including brain damage and genetic causes [85]. Broadly, seizures can be classified into focal and generalized seizures. Focal seizures are typically localized to one brain hemisphere and may arise from insults such as localized brain lesions, or tumors. In contrast, generalized epilepsies are characterized by seizure activity over both brain hemispheres. They can be further classified into symptomatic and idiopathic epilepsy. Symptomatic generalized seizures can be caused by insults such as brain infection or oxygen deprivation. Idiopathic seizures often do not have a clear etiology, but may often include a genetic component $[10$, 59]. One of the key defining attributes of idiopathic generalized epilepsies (IGEs) is the

Address for correspondence: Edward Perez-Reyes, Department of Pharmacology, University of Virginia, Charlottesville, VA 29908, U.S.A., eperez@virginia.edu. 
occurrence of absence seizures [22]. Absence seizures are typically short in duration and manifest themselves as sudden behavioral arrest and impaired consciousness followed by sudden termination and return to normal behavior. In electroencephalogram (EEG) recordings, absence seizures are characterized by spike and wave discharges (SWDs) that arise from synchronous firing of thalamocortical networks [11].

The onset of IGE typically occurs in childhood, although adult onset may also occur [52]. Indeed, among epilepsies involving absence seizures, childhood absence epilepsy CAE) and juvenile absence epilepsy (JAE) are the most common forms of IGE. CAE has been extensively investigated at the cellular and network levels in both animals and humans, revealing a strong causal link to mutations in various types of voltage-gated and ligandgated ion channels, including voltage-gated potassium, sodium, and calcium channels, as well as $\mathrm{GABA}_{\mathrm{A}}$ receptors $[33,50,59,82]$. Here, we shall focus on the role of voltage-gated calcium channels in the development of IGEs.

\section{Subtypes, subunit composition, and selected physiological roles of voltage gated calcium channels}

Voltage-gated calcium channels can be classified, based on their biophysical characteristics, into high voltage activated (HVA) and low voltage activated (LVA) channels, with HVA channels requiring larger membrane depolarizations for activation. HVA channels can be further subdivided into L-, N-, P-, Q- and R-types, by virtue of their distinct functional and pharmacological profiles (Fig. 1A). Members of the HVA channel family are heteromultimers of a pore forming $\alpha 1$ subunit that coassembles with ancillary $\beta, \alpha_{2} \delta$ (and in some cases a $\gamma$ subunit) into a functional channel complex (Fig. 1B) [6, 19]. In contrast, LVA channels (also referred to as T-type) are thought to be $\alpha 1$ subunit monomers (Fig. 1C). The $\alpha 1$ subunit defines the channel subtype, whereas the ancillary subunits modulate $\alpha 1$ subunit function and surface expression. The $\alpha 1$ subunit is comprised of four homologous membrane repeats (each containing six transmembrane helices termed S1 through S6, plus a pore lining P-loop motif) that are connected via cytoplasmic linker regions and flanked by cytoplasmic $\mathrm{N}$ - and $\mathrm{C}$-termini. Ten different $\alpha 1$ subunit subtypes belonging to three large families are expressed in the mammalian genome (Fig. 1A). The $\mathrm{Ca}_{\mathrm{v}} 1$ family encodes Ltype calcium channels and includes four different members $\left(\mathrm{Ca}_{\mathrm{v}} 1.1\right.$ through $\left.\mathrm{Ca}_{\mathrm{v}} 1.4\right)$. The $\mathrm{Ca}_{\mathrm{v}} 2$ family includes $\mathrm{Ca}_{\mathrm{v}} 2.1, \mathrm{Ca}_{\mathrm{v}} 2.2$ and $\mathrm{Ca}_{\mathrm{v}} 2.3$, which encode P/Q-type, N-type and Rtype channels, respectively. The $\mathrm{Ca}_{\mathrm{v}} 3$ encompasses the family of T-type channels with three members $\left(\mathrm{Ca}_{\mathrm{v}} 3.1\right.$ through $\left.\mathrm{Ca}_{\mathrm{v}} 3.3\right)$. Of particular note, P- and Q-type channels appear to arise from alternate splicing of $\mathrm{Ca}_{\mathrm{v}} 2.1$ and possibly the coassembly with distinct $\beta$ subunits $[12,67]$. Vertebrates express four different types of calcium channel $\beta$ subunits $\left(\beta_{1}\right.$ through $\left.\beta_{4}\right)$, four different types of $\alpha_{2} \delta$ subunits $\left(\alpha_{2} \delta 1\right.$ through $\left.\alpha_{2} \delta 4\right)$, and as many as 8 different $\gamma$ subunits $[6,9]$ (Fig. 1B). The $\beta$ subunits are cytoplasmic proteins that interact with the linker joining repeats I \& II of the calcium channel $\alpha 1$ subunit and strongly modulate channel properties such as inactivation rates [6]. Moreover, these subunits play a major role in targeting the channels to the plasma membrane. The $\alpha_{2} \delta$ subunit is encoded by a single gene, and it is post-translationally cleaved into a transmembrane $\delta$ subunit that remains di-sulfide linked to an extracellular $\alpha_{2}$ subunit $[25,44]$. The $\gamma$ subunit includes four transmembrane helices and was first identified as part of the skeletal muscle L-type channel complex [3]. Since then, a number of neuronal $\gamma$ subunits have been cloned; however, it is not entirely clear if they are bona fide calcium channel subunits. Functional effects on both HVA and LVA calcium channel activity have been reported in expression systems [68], but a much more pronounced role has been ascribed to $\gamma$ subunits in the context of regulating AMPA receptor trafficking and function [78]. 
The different types of calcium channel $\alpha 1$ subunits are differentially distributed within neurons. In the context of this review, it is important to note that P/Q-type, N-type, and, to some extent, R-type channels are expressed highly at presynaptic nerve terminals where their activities evoke neurotransmitter release [80]. T-type calcium channels tend to be expressed at cell bodies and dendrites [55], where they contribute to the regulation of neuronal excitability [63]. Taken together, P/Q-type and T-type calcium channels show distinct functional properties, subunit composition, and subcellular distributions, and they serve distinct physiological roles, and yet, they both are major contributors to the development of absence seizures and IGE.

\section{P/Q-type channels and absence seizures}

As noted above, $\mathrm{Ca}_{\mathrm{v}} 2.1$ (P/Q-type) calcium channels are important mediators of synaptic transmission in central and peripheral neurons. As a result, changes in the functional properties of $\mathrm{Ca}_{\mathrm{v}} 2.1$ channels may be expected to alter the behavior of neuronal networks. A possible role of $\mathrm{P} / \mathrm{Q}$-type channels in seizure disorders is readily apparent when considering the phenotypes of $\mathrm{Ca}_{\mathrm{v}} 2.1$ channel $\mathrm{KO}$ mice. These mice show severe ataxia and die about four weeks after birth [42]. Moreover, they display absence seizures, indicating that P/Qtype channels may protect from the occurrence of such seizure activity during normal physiology. Additional evidence implicating $\mathrm{Ca}_{\mathrm{v}} 2.1$ channels in absence seizures comes from several murine mouse models with $\mathrm{P} / \mathrm{Q}$-type channel mutations (Fig. 2A). In tottering $(\mathrm{tg})$ mice, a proline residue in the repeat II S5-S6 region of $\mathrm{Ca}_{\mathrm{v}} 2.1$ is substituted by a leucine residue [26, 32], leading to a reduction of P/Q-type channel activity as assayed in both neurons and in expression systems [88]. Consistent with their role in neurotransmitter release, the reduced P/Q-type channel function in these mice is paralleled by altered neurotransmitter release in cortical neurons [4], and reduced excitatory synaptic potentials evoked in thalamic neurons [17]. Similar to the $\mathrm{Ca}_{\mathrm{v}} 2.1 \mathrm{KO}$ mice, $t g$ mice show cerebellar ataxia and absence seizures with 5-7 Hz SWDs [32, 61]. The $\mathrm{Ca}_{\mathrm{v}} 2.1$ calcium channel gene of leaner $\left(\mathrm{tg}^{\mathrm{la}}\right)$ mice exhibits a frameshift mutation in the C-terminal region, which results in a premature stop [26, 32]. This reportedly results in altered P/Q-type channel currents, as well as reduced neurotransmitter release at neocortical synapses [4]. The $t g^{l a}$ mice display cortical SWDs that are consistent with absence seizures and, are, again, severely ataxic [32, 51]. Finally, in the $\mathrm{Ca}_{\mathrm{v}} 2.1$ channels of Rocker ( $\left.r k r\right)$ mice, a lysine residue in the repeat III S5-S6 region is replaced with a threonine [98]; however, it remains unclear what effects this mutation has on the biophysics of the channel. Nonetheless, these mice show spontaneous bilateral 6-7 Hz SWDs accompanied by behavioral arrest, typical of absence seizures [98].

A few other mutations associated with seizure activity have been mapped to the $\mathrm{Ca}_{\mathrm{v}} 2.1$ subunit in mice, including rolling Nagoya $\left({ }^{r o l}{ }^{r o l}\right.$ ) and wobbly ( $w b$; Fig. 2A). Most of these mouse genotypes and their associated phenotypes, except wobbly [91], show a recessive inheritance pattern and, at least in the $t g$ and $t g^{l a}$ mice, seem to parallel the phenotype of the $\mathrm{Ca}_{\mathrm{v}} 2.1$ channel KO mouse. This may be due to the fact that both mutant mice show reduced $\mathrm{Ca}_{\mathrm{v}} 2.1$ channel activity, which would be equivalent to a partial $\mathrm{Ca}_{\mathrm{v}} 2.1$ knockdown. Importantly, all these mouse mutants also exhibit ataxia, possibly due to reduced P/Q-type channel activity and unbalanced excitatory/inhibitory neurotransmitter release in the cerebellum, since the P/Q-current accounts for $\sim 90 \%$ of the total calcium current in Purkinje neurons [58].

In humans, mutations in P/Q-type calcium channels are more frequently associated with conditions such as episodic ataxia type 2 (EA-2) and familial hemiplegic migraine type 1 (FHM1) [reviewed in [64] and [65]], both of which are dominantly inherited (Fig. 2B). Ataxia is then a common phenotype in both mice and men with $\mathrm{Ca}_{\mathrm{v}} 2.1$ mutations. Importantly, there are some instances in which patients with $\mathrm{Ca}_{\mathrm{v}} 2.1$ mutations present with 
absence seizures (illustrated in Fig. 2B). For example, a truncation mutation in the Cterminal region of $\mathrm{Ca}_{\mathrm{v}} 2.1$ that results in a non-functional channel has been associated with the occurrence of childhood episodes of absence epilepsy and primary generalized seizures in a patient with episodic ataxia type 2 [41]. Another mutation in the repeat I-S2 region is found in a different family of patients, which reduces P/Q-type channel activity and gives rise to an ataxic and epileptic phenotype [40]. An 11 year old girl with a missense mutation $(\mathrm{I} 712 \mathrm{~V})$ in the $\mathrm{Ca}_{\mathrm{v}} 2.1$ channel was recently described to have a range of symptoms, including seizures, headache, and ataxia [35], but the effect of the mutation on channel gating has not yet been determined. In patients with FHM associated with P/Q-type channel mutations, the occurrence of seizures is exceedingly rare and limited to only a few case reports [27]. This may be due to the notion that FHM appears to arise from a gain of function of $\mathrm{Ca}_{\mathrm{v}} 2.1$, rather than a loss of function $[18,79]$. Altogether, in both humans and rodents, mutations that give rise to diminished P/Q-type channel function have the propensity to cause absence seizures. As noted below, in these rodent models there is also a compensatory increase in T-currents of thalamic relay neurons [94], which likely underlies their seizure phenotype.

\section{Ancillary calcium channel subunits and seizures}

As noted above, HVA calcium channels are multi-subunit complexes where the ancillary subunits regulate channel function and/or membrane expression of the pore-forming $\alpha 1$ subunit. As such, one may expect loss of function mutations in ancillary subunits of $\mathrm{Ca}_{\mathrm{v}} 2.1$ channels would reduce its channel activity and perhaps produce an epileptic phenotype in vivo. In mice, mutations associated with seizure activity have indeed been found in all major classes of ancillary calcium channel subunits (Fig. 2A). The lethargic (lh) mouse arises from a frameshift mutation in the calcium channel $\beta_{4}$ subunit, thus resulting in an effective knockout of this subunit. These mice exhibit absence seizures, ataxia, and reduced excitatory neurotransmitter release [16]. It is interesting to note that similar mutations at splice junctions have been found in the $\beta_{4}$ gene in two families displaying IGE [30].

There are also several mouse phenotypes associated with mutations in $\alpha_{2} \delta$ subunits, including two mutations which cause a loss of $\alpha_{2} \delta 2$ subunit protein and which give rise to two strains of $d u c k y$ mice $\left(d u\right.$ and $d u^{2 J}$ ). These mice show 5-7 Hz SWD during seizure episodes, as well as behavioral arrest and ataxia [5]. In transient expression systems, the coexpression of the mutated recombinant subunits reduces the amount of $\mathrm{Ca}_{\mathrm{v}} 2.1$ current [14], again, consistent with the idea that reduced $\mathrm{Ca}_{\mathrm{v}} 2.1$ channel function may lead to the appearance of absence seizures. In the entla (ent) mouse, a duplication of an exon 3 interferes with the disulfide linkage of the $\alpha_{2}$ and $\delta 2$ subunits, thus rendering the subunits non-functional [13]. These mice also have reduced P/Q-type currents in the hippocampus, as well as $2-4 \mathrm{~Hz}$ SWDs in the cortex and hippocampus.

The stargazer (stg) and waggler ( $\mathrm{wgl}$ ) mice arise from dysfunctional calcium channel $\gamma_{2}$ subunits (also referred to as stargazin). Their phenotypes are characterized by absence seizures and episodes of head tossing [45, 46]. Seizures are further exacerbated in waggler mice by knockout of the $\gamma_{4}$ subunit [47]. In stg mice, there is a small reduction in P/Q-type channel activity due to shifts in the midpoint of the steady state inactivation curve of the channel, as assayed in Xenopus oocytes [reviewed in [9]]. In view of the known effects of stargazin on AMPA receptors, it is difficult to unequivocally attribute the physiological effects of truncation mutations in stargazin to an alteration of calcium channel function.

\section{Role of T-type channels in neuronal excitability}

Entry of $\mathrm{Ca}^{2+}$ ions through T-channels leads to depolarization of the membrane, allowing Tcurrents to generate low threshold spikes (LTS) that trigger bursts of Na-dependent action 
potentials [49]. This role is especially prominent in thalamic neurons, which express Tcurrents at very high densities (reviewed in [63]). Thalamic neurons form a reciprocally connected circuit that oscillates during natural processes like sleep, but can also oscillate at inappropriate times, as during a generalized seizure [53]. This circuit is composed of thalamic reticular neurons (nRT; GABAergic), thalamocortical neurons that reside in the relay nuclei (TC, glutamatergic), and cerebral cortical neurons (glutamatergic). The unique voltage dependence of T-channels allows them to generate LTS after either an inhibitory or excitatory post-synaptic potential (IPSP, EPSP). Rebound firing after an IPSP occurs because $\mathrm{T}$-channels are inactivated at the resting membrane potential of many neurons, then recover from inactivation during an IPSP. As the IPSP decays and the resting membrane potential is restored, T-channels can open and create a LTS. Another very interesting property of T-channels is their ability to generate "window currents." Window currents arise when a channel is available to open at a given potential and not totally inactivated. They are operationally defined by the overlap of the steady-state activation and inactivation curves. Notably, T-window currents occur at the resting membrane potential of most neurons, allowing them to contribute to membrane bistability; e.g. thalamic neurons have two "resting" membrane potentials, one around $-77 \mathrm{mV}$, and a second around $-60 \mathrm{mV}$ [23]. $\mathrm{Ca}_{\mathrm{v}} 3.2$ channels have been shown to generate window currents and increase resting basal $\mathrm{Ca}^{2+}$ concentrations [20].

T-channels open and close at negative membrane potentials, where there is a large driving force for $\mathrm{Ca}^{2+}$ entry. Their opening can lead to robust increases in intracellular $\mathrm{Ca}^{2+}$, especially in small compartments such as dendrites $[60,97] . \mathrm{Ca}^{2+}$ entry via T-channels has also been shown to cause Ca-induced Ca-release (CICR) from internal stores, which can trigger a form of long-term depression in hippocampal neurons [62, 89]. In some neurons, $\mathrm{Ca}^{2+}$ influx via T-channels dampens excitability by opening Ca-activated $\mathrm{K}^{+}$channels, which contributes to spike repolarization and after-hyperpolarizations [24, 48, 83, 90]. In summary, T-channels play important physiological roles by controlling membrane potential and by controlling intracellular $\mathrm{Ca}^{2+}$ concentrations.

\section{Upregulation of T-type channels in epilepsy}

There is significant evidence that T-channels play a role in epilepsy and pain. In particular, T-channels are thought to play an important role in idiopathic generalized epilepsies (IGE), such as absence epilepsy, due to their high expression in the thalamus. In addition to being supported by pharmacology studies, this hypothesis is further supported by studies in the GAERS model of absence epilepsy. Reticular thalamic neurons isolated from these rats have 55\% larger T-currents than the control strain and show a $16 \%$ increase in $\mathrm{Ca}_{\mathrm{v}} 3.2$ mRNA [75, 81]. Similar results were found in the WAG/Rij model of absence epilepsy [15]. It is interesting to note that increased T-type calcium channel activity was first implicated in studies of mice with absence seizure phenotypes, where the underlying mutation is in high voltage-activated channels [94]. This result provides a clear example of how misleading the correlation between phenotype and gene knockout can be. Examples of this phenomenon include: tottering mice with $\mathrm{Ca}_{\mathrm{v}} 2.1$ mutations; stargazer mice with mutations in $\gamma 2$; and lethargic mice with mutations in $\beta 4$. Mutations in non-calcium channel genes also lead to absence epilepsy in the mouse model Coloboma, and increases in T-currents increase prior to the onset of epilepsy [95]. The hypothesis that increased T-currents play a direct role in epileptogenesis is provided by inducing epilepsy by forced overexpression of $\mathrm{Ca}_{\mathrm{v}} 3.1$ currents [29], and by "curing" tottering, stargazer, and lethargic mice by crossing with $\mathrm{Ca}_{\mathrm{v}} 3.1$ knockout mice [71]. It remains to be determined whether the absence seizures arise from the ability of increased T-currents to alter membrane excitability or intracellular calcium concentrations, although it should be noted that early modeling studies suggested a 2 -fold increase in T-currents would be sufficient to induce oscillations of thalamocortical 
circuitry [54]. Similarly, a recent modeling study concluded that small changes $(2-3 \mathrm{mV}$, which would be virtually undetectable) in the voltage dependence of activation of $\mathrm{Na}^{+}$or $\mathrm{Ca}^{2+}$ channels could underlie seizures [77]. Indeed, over-activity of T-channels appears critical, as demonstrated by the observation that transgenic mice overexpressing $\mathrm{Ca}_{\mathrm{v}} 3.1$ channels display spike-and wave-discharges, the EEG signature of absence epilepsy [29]. This provided strong evidence that primary elevation of T-type channel activity is sufficient to induce a pure absence epilepsy phenotype. Conversely, a small reduction in T-currents by the anti-absence seizure medication, ethosuximide, may be sufficient to reduce oscillation of thalamocortical circuits in vitro [39]. Indeed, a recent study has documented that a selective T-channel blocker exhibits strong efficacy in suppression of absence seizures in the genetic rat model WAG/Rij [93].

T-currents are also upregulated in CA1 hippocampal neurons in the pilocarpine model of temporal lobe epilepsy (TLE) $[7,74]$. The original observation was that pilocarpine-induced status epilepticus promoted spontaneous firing of CA1 neurons [74]. A subsequent study using focal application of $\mathrm{Ni}^{2+}$ and amiloride implicated upregulation of T-currents in apical dendrites [92]. A recent study established the role of $\mathrm{Ca}_{\mathrm{v}} 3.2$ channels in this form of epilepsy using $\mathrm{Ca}_{\mathrm{v}} 3.2(-/-)$ mice [7]. Interestingly, the strength of synaptic inputs into CA1 neurons is altered in this model of TLE with a dramatic increase in the entorhinal cortex (EC) input via the temporoammonic pathway [1]. These inputs terminate in the most distal dendrites in the stratum lacunosum-moleculare [56]. Although other factors may be involved, a plausible explanation is that upregulation of $\mathrm{Ca}_{\mathrm{v}} 3.2$ channels boosts EPSPs triggered in distal dendrites. Hippocampal T-current density is also increased after electrical kindling [31]. These animal models mimic human temporal lobe and focal epilepsies, implicating possible upregulation of T-currents in many forms of epilepsy.

\section{CACNA1H is an epilepsy susceptibility gene}

The word mutation has two connotations. To a molecular biologist, a mutation is any change in the nucleotide sequence that differs from a standard reference sequence (e.g. the GenBank). To a geneticist, a mutation is a change in nucleotide sequence that has been shown to cause disease. This strict interpretation requires that the term mutation only applies to monogenic autosomal dominant disorders. Monogenic disorders that cause epilepsy are relatively rare [57]. In contrast, idiopathic generalized epilepsy (IGE) is a polygenic disorder $[34,38,69,76,84]$. The first evidence that IGE was a polygenic disorder came from Dr. Lennox's study of epilepsy in twins [84]. He found that even in monozygotic twins there was only a $75 \%$ concordance for absence epilepsy, with a $0 \%$ concordance in dizygotic twins. Other characteristics of polygenic disorders found in absence epilepsy include a variable age of onset, variable age of recovery, and periodicity [34]. Furthermore, generalized spike-and-wave discharges have been observed in family members who do not have seizures [69]. Finally, the conclusion from many linkage studies is that the complex pattern of IGE inheritance is not due to a single gene, but that "each gene contributes a small or modest effect to the epilepsy phenotype, and by itself is insufficient to cause epilepsy. These are "susceptibility genes" [76]. Therefore, common single nucleotide polymorphisms (SNPs) can contribute to epilepsy susceptibility. More importantly, a large number of SNPs have been found only in epilepsy patients (Fig. 3). We will refer to these as "variants." The first of these studies was performed on Childhood Absence Epilepsy (CAE) patients in China, leading to the identification of 12 specific variants in $C A C N A 1 H$ associated with CAE [21]. Interestingly, patients from 3 distinct families harbored both the G773D variant and "common" SNP R788C, which was found in 20\% of CAE patients and in 10\% of the general population [87]. A second study extended the finding of $C A C N A 1 H$ variants to many related epilepsies, such as juvenile absence, juvenile myoclonic epilepsy (JME), febrile seizures, and temporal lobe epilepsy (TLE) [36]. Sequence variations in the $\mathrm{Ca}_{\mathrm{v}} 3.2$ 
gene, $C A C N A 1 H$, have also been linked to Autism Spectrum Disorders (ASD) [72]. In addition, variants were detected in the $\mathrm{Ca}_{\mathrm{v}} 3.1$ gene, $C A C N A 1 G$, in IGE patients, although no phenotypic differences were noted in channel behavior [70]. Studies on the Generalized Absence Epilepsy Rat of Strasbourg (GAERS) confirmed this conclusion, as a variant in the III-IV loop (Fig. 1) accounts for some, but not all, of the seizure phenotype [66]. Notably, this variant, R1584P, alters the ratio of III-IV loop splice variants, favoring the variant with faster recovery from inactivation. Similarly, IGE of the human $C A C N A 1 H$ gene, supporting the hypothesis that variants simply alter the ratio of splice variants with unique properties, but do not themselves induce novel phenotypes [96]. In crosses of GAERS with control rats, the R1584P mutation segregated with seizures (percentage time and total number of seizures). Interestingly, a subset of rats did not inherit the mutation, yet were still prone to seizures, and vice versa. Taken together, these studies on both humans and animal models clearly establish that IGE is a polygenic disorder, and that sequence variations in $C A C N A I H$ can contribute to seizure susceptibility.

Despite considerable progress in defining the role of calcium channels in epilepsy, there remain many unanswered questions. How do these $\mathrm{Ca}_{\mathrm{v}} 3$ variants increase seizure susceptibility? In the most simplistic sense, epilepsy is a disorder in which the balance between excitatory and inhibitory neurotransmission is tipped towards excitability. Therefore, one can predict that T-channel variants might cause changes in gating that would increase seizure susceptibility, such as: 1) shifting the voltage-dependence of activation; 2) shifting the voltage dependence of inactivation; 3) accelerating channel opening; slowing channel inactivation; 4) slowing deactivation (open to close transitions); 5) accelerating recovery; 6) increasing the probability of channel opening $\left(\mathrm{P}_{\mathrm{o}}\right)$; and 7) increasing single channel conductance. Notably, variants associated with IGE do affect many of these properties [43, 87]. Surprisingly, some of the $\mathrm{Ca}_{\mathrm{v}} 3.2$ variants found in IGE patients had no detectable effect on channel biophysics. During a structure-function study it was discovered that the loop connecting repeat I to II (I-II loop; Fig. 1) played a role in channel expression [2]. This study went on to show that all CAE variants located in this loop increased surface expression, thereby providing a unifying mechanism for their role in seizure susceptibility [86]. Mechanisms by which this might occur include: enhanced trafficking out of ER/Golgi to plasma membrane (PM); slower retrieval from PM; altered fate of internalized early endosomes from degradation to PM recycling; and altered distribution of T-channels in neurons, e.g. enhanced trafficking into dendrites or axon hillock. Another unresolved question is: Do the $\mathrm{Ca}_{\mathrm{v}} 3$ variants alter trafficking to dendrites? Based on their known roles in dendritic physiology [73], this would likely have significant effects on burst firing and synaptic integration. Finally, we would like to emphasize the difficulty in demonstrating that a channel variant is the root cause of epilepsy, because IGE is a polygenic disorder and by definition, requires the co-inheritance of variants in other genes (nature), as well as contributions from the environment (nurture) $[8,77]$.

\section{Acknowledgments}

GWZ is a Scientist of the Alberta Heritage Foundation for Medical Research and a Canada Research Chair in Molecular Neurobiology. PL is supported by CNRS and grants from ANR (ANR-2006-Neuro35) and Fédération pour la Recherche sur le Cerveau. EPR is supported by grants from NIH (NS067456).

\section{References}

1. Ang CW, Carlson GC, Coulter DA. Massive and specific dysregulation of direct cortical input to the hippocampus in temporal lobe epilepsy. J Neurosci. 2006; 26:11850-11856. [PubMed: 17108158]

2. Arias JM, Murbartián J, Vitko I, et al. Transfer of $\beta$ subunit regulation from high to low voltagegated $\mathrm{Ca}^{2+}$ channels. FEBS Lett. 2005; 579:3907-3912. [PubMed: 15987636] 
3. Arikkath J, Campbell KP. Auxiliary subunits: essential components of the voltage-gated calcium channel complex. Curr Opin Neurobiol. 2003; 13:298-307. [PubMed: 12850214]

4. Ayata C, Shimizu-Sasamata M, Lo EH, et al. Impaired neurotransmitter release and elevated threshold for cortical spreading depression in mice with mutations in the $\alpha 1 \mathrm{~A}$ subunit of P/Q type calcium channels. Neurosci. 1999; 95:639-645.

5. Barclay J, Balaguero N, Mione M, et al. Ducky mouse phenotype of epilepsy and ataxia is associated with mutations in the Cacna2d2 gene and decreased calcium channel current in cerebellar Purkinje cells. J Neurosci. 2001; 21:6095-6104. [PubMed: 11487633]

6. Baumgart, JP.; Perez-Reyes, E. Voltage-gated $\mathrm{Ca}^{2+}$ channels. In: Kew, JN.; Davies, C., editors. Ion channels: from structure to function. Oxford University Press; London: 2009.

7. Becker AJ, Pitsch J, Sochivko D, et al. Transcriptional upregulation of $\mathrm{Ca}_{\mathrm{v}} 3.2$ mediates epileptogenesis in the pilocarpine model of epilepsy. J Neurosci. 2008; 28:13341-13353. [PubMed: 19052226]

8. Berkovic SF, Mulley JC, Scheffer IE, et al. Human epilepsies: interaction of genetic and acquired factors. Trends Neurosci. 2006; 29:391-397. [PubMed: 16769131]

9. Black JL 3rd. The voltage-gated calcium channel $\gamma$ subunits: a review of the literature. J Bioenerg Biomembr. 2003; 35:649-660. [PubMed: 15000525]

10. Blumenfeld H. From molecules to networks: cortical/subcortical interactions in the pathophysiology of idiopathic generalized epilepsy. Epilepsia. 2003; 44(Suppl 2):7-15. [PubMed: 12752456]

11. Blumenfeld H. Cellular and network mechanisms of spike-wave seizures. Epilepsia. 2005; 46(Suppl 9):21-33. [PubMed: 16302873]

12. Bourinet E, Soong TW, Sutton K, et al. Splicing of $\alpha_{1 \mathrm{~A}}$ subunit gene generates phenotypic variants of P- and Q-type calcium channels. Nat Neurosci. 1999; 2:407-415. [PubMed: 10321243]

13. Brill J, Klocke R, Paul D, et al. entla, a novel epileptic and ataxic Cacna2d2 mutant of the mouse. J Biol Chem. 2004; 279:7322-7330. [PubMed: 14660671]

14. Brodbeck J, Davies A, Courtney JM, et al. The ducky mutation in cacna2d2 results in altered Purkinje cell morphology and is associated with the expression of a truncated $\alpha_{2} \delta$-2 protein with abnormal function. J Biol Chem. 2002; 277:7684-7693. [PubMed: 11756448]

15. Broicher T, Kanyshkova T, Meuth P, et al. Correlation of T-channel coding gene expression, I(T), and the low threshold $\mathrm{Ca}(2+)$ spike in the thalamus of a rat model of absence epilepsy. Mol Cell Neurosci. 2008

16. Burgess DL, Jones JM, Meisler MH, et al. Mutation of the $\mathrm{Ca}^{2+}$ channel subunit gene $C$ chb4 is associated with ataxia and seizures in the lethargic $(l h)$ mouse. Cell. 1997; 88:385-392. [PubMed: 9039265]

17. Caddick SJ, Wang C, Fletcher CF, et al. Excitatory but not inhibitory synaptic transmission is reduced in lethargic $\left(\mathrm{Cacnb}^{l h}\right)$ and tottering $\left(\right.$ Cacnala $\left.{ }^{\text {tg }}\right)$ mouse thalami. J Neurophysiol. 1999; 81:2066. [PubMed: 10322048]

18. Catterall WA, Dib-Hajj S, Meisler MH, et al. Inherited neuronal ion channelopathies: new windows on complex neurological diseases. J Neurosci. 2008; 28:11768-11777. [PubMed: 19005038]

19. Catterall WA, Perez-Reyes E, Snutch TP, et al. International Union of Pharmacology. XLVIII. Nomenclature and structure-function relationships of voltage-gated calcium channels. Pharmacol Rev. 2005; 57:411-425. [PubMed: 16382099]

20. Chemin J, Monteil A, Briquaire C, et al. Overexpression of T-type calcium channels in HEK-293 cells increases intracellular calcium without affecting cellular proliferation. FEBS Lett. 2000; 478:166-172. [PubMed: 10922490]

21. Chen YC, Lu JJ, Pan H, et al. Association between genetic variation of CACNA1H and childhood absence epilepsy. Ann Neurol. 2003; 54:239-243. [PubMed: 12891677]

22. Commission on classification and terminology of the International League Against Epilepsy. Proposal for revised classification of epilepsies and epileptic syndromes. Epilepsia. 1989; 30:389399. [PubMed: 2502382]

23. Crunelli V, Toth TI, Cope DW, et al. The T-type calcium current in brain dynamics of different behavioural states. J Physiol (Lond). 2005; 562:121-129. [PubMed: 15498803] 
24. Cueni L, Canepari M, Lujan R, et al. T-type $\mathrm{Ca}^{2+}$ channels, SK2 channels and SERCAs gate sleeprelated oscillations in thalamic dendrites. Nat Neurosci. 2008; 11:683-692. [PubMed: 18488023]

25. De Jongh KS, Warner C, Catterall WA. Subunits of purified calcium channels. $\alpha 2$ and $\delta$ are encoded by the same gene. J Biol Chem. 1990; 265:14738-14741. [PubMed: 2168391]

26. Doyle J, Ren X, Lennon G, et al. Mutations in the Cacnlla4 calcium channel gene are associated with seizures, cerebellar degeneration, and ataxia in tottering and leaner mutant mice. Mammalian Genome. 1997; 8:113-120. [PubMed: 9060410]

27. Ducros A, Denier C, Joutel A, et al. The clinical spectrum of familial hemiplegic migraine associated with mutations in a neuronal calcium channel. N Engl J Med. 2001; 345:17-24. [PubMed: 11439943]

28. Engel, J.; Pedley, TA.; Aicardi, J., et al., editors. Epilepsy: A comprehensive textbook. Lippincott Williams \& Wilkins; Philadelphia:

29. Ernst WL, Zhang Y, Yoo JW, et al. Genetic enhancement of thalamocortical network activity by elevating $\alpha 1 \mathrm{G}$-mediated low-voltage-activated calcium current induces pure absence epilepsy. $\mathrm{J}$ Neurosci. 2009; 29:1615-1625. [PubMed: 19211869]

30. Escayg A, De Waard M, Lee DD, et al. Coding and noncoding variation of the human calciumchannel $\beta_{4}$-subunit gene $C A C N B 4$ in patients with idiopathic generalized epilepsy and episodic ataxia. Am J Hum Genet. 2000; 66:1531-1539. [PubMed: 10762541]

31. Faas GC, Vreugdenhil M, Wadman WJ. Calcium currents in pyramidal CA1 neurons in vitro after kindling epileptogenesis in the hippocampus of the rat. Neurosci. 1996; 75:57-67.

32. Fletcher CF, Lutz CM, O'xSullivan TN, et al. Absence epilepsy in tottering mutant mice is associated with calcium channel defects. Cell. 1996; 87:607-617. [PubMed: 8929530]

33. Gardiner RM. Genetic basis of the human epilepsies. Epilepsy Res. 1999; 36:91-95. [PubMed: 10515157]

34. Gargus JJ. Unraveling monogenic channelopathies and their implications for complex polygenic disease. Am J Hum Genet. 2003; 72:785-803. [PubMed: 12629596]

35. Guerin AA, Feigenbaum A, Donner EJ, et al. Stepwise developmental regression associated with novel CACNA1A mutation. Pediatr Neurol. 2008; 39:363-364. [PubMed: 18940563]

36. Heron SE, Khosravani H, Varela D, et al. Extended spectrum of idiopathic generalized epilepsies associated with CACNA1H functional variants. Ann Neurol. 2007; 62:560-568. [PubMed: 17696120]

37. Heron SE, Phillips HA, Mulley JC, et al. Genetic variation of $C A C N A 1 H$ in idiopathic generalized epilepsy. Ann Neurol. 2004; 55:595-596. [PubMed: 15048902]

38. Heron SE, Scheffer IE, Berkovic SF, et al. Channelopathies in idiopathic epilepsy. Neurotherapeutics. 2007; 4:295-304. [PubMed: 17395140]

39. Huguenard JR, Prince DA. Intrathalamic rhythmicity studied in vitro: nominal T-current modulation causes robust antioscillatory effects. J Neurosci. 1994; 14:5485-5502. [PubMed: 8083749]

40. Imbrici P, Jaffe SL, Eunson LH, et al. Dysfunction of the brain calcium channel Cav2.1 in absence epilepsy and episodic ataxia. Brain. 2004; 127:2682-2692. [PubMed: 15483044]

41. Jouvenceau A, Eunson LH, Spauschus A, et al. Human epilepsy associated with dysfunction of the brain P/Q-type calcium channel. The Lancet. 2001; 358:801-807.

42. Jun K, Piedras-Renteria ES, Smith SM, et al. Ablation of P/Q-type $\mathrm{Ca}^{2+}$ channel currents, altered synaptic transmission, and progressive ataxia in mice lacking the alpha $1 \mathrm{~A}^{\text {-subunit. Proc Natl Acad }}$ Sci USA. 1999; 96:15245-15250. [PubMed: 10611370]

43. Khosravani H, Zamponi GW. Voltage-gated calcium channels and idiopathic generalized epilepsies. Physiol Rev. 2006; 86:941-966. [PubMed: 16816142]

44. Klugbauer N, Lacinová L, Marais E, et al. Molecular diversity of the calcium channel $\alpha_{2} \delta$ subunit. J Neurosci. 1999; 19:684-691. [PubMed: 9880589]

45. Letts VA, Felix R, Biddlecome GH, et al. The mouse stargazer gene encodes a neuronal $\mathrm{Ca}^{2+}$ channel $\gamma$ subunit. Nat Genet. 1998; 19:340-347. [PubMed: 9697694]

46. Letts VA, Kang MG, Mahaffey CL, et al. Phenotypic heterogeneity in the stargazin allelic series. Mamm Genome. 2003; 14:506-513. [PubMed: 12925883] 
47. Letts VA, Mahaffey CL, Beyer B, et al. A targeted mutation in Cacng4 exacerbates spike-wave seizures in stargazer (Cacng2) mice. Proc Natl Acad Sci USA. 2005; 102:2123-2128. [PubMed: 15677329]

48. Llinás R, Yarom Y. Properties and distribution of ionic conductances generating electroresponsiveness of mammalian inferior olivary neurones in vitro. J Physiol (Lond). 1981; 315:569-584. [PubMed: 7310722]

49. Llinás RR. The intrinsic electrophysiological properties of mammalian neurons: insights into central nervous system function. Science. 1988; 242:1654-1664. [PubMed: 3059497]

50. Lorenzon, NM.; Beam, KG. Channels. Austin, Tex: 2008. Disease causing mutations of calcium channels; p. 2

51. Lorenzon NM, Lutz CM, Frankel WN, et al. Altered calcium channel currents in Purkinje cells of the neurological mutant mouse leaner. J Neurosci. 1998; 18:4482-4489. [PubMed: 9614225]

52. Marini C, King MA, Archer JS, et al. Idiopathic generalised epilepsy of adult onset: clinical syndromes and genetics. J Neurol Neurosurg Psychiatry. 2003; 74:192-196. [PubMed: 12531947]

53. McCormick DA, Contreras D. On the cellular and network bases of epileptic seizures. Annu Rev Physiol. 2001; 63:815-846. [PubMed: 11181977]

54. McCormick DA, Huguenard JR. A model of the electrophysiological properties of thalamocortical relay neurons. J Neurophysiol. 1992; 68:1384-1400. [PubMed: 1331356]

55. McKay BE, McRory JE, Molineux ML, et al. $\mathrm{Ca}_{\mathrm{v}} 3$ T-type calcium channel isoforms differentially distribute to somatic and dendritic compartments in rat central neurons. European Journal of Neuroscience. 2006; 24:2581-2594. [PubMed: 17100846]

56. Megías M, Emri Z, Freund TF, et al. Total number and distribution of inhibitory and excitatory synapses on hippocampal CA1 pyramidal cells. Neurosci. 2001; 102:527-540.

57. Meisler MH, Kearney J, Ottman R, et al. Identification of epilepsy genes in human and mouse. Annu Rev Genet. 2001; 35:567-588. [PubMed: 11700294]

58. Mintz IM, Adams ME, Bean BP. P-type calcium channels in rat central and peripheral neurons. Neuron. 1992; 9:85-95. [PubMed: 1321648]

59. Mulley JC, Scheffer IE, Harkin LA, et al. Susceptibility genes for complex epilepsy. Hum Mol Genet. 2005; 14(Spec No 2):R243-249. [PubMed: 16244322]

60. Munsch T, Budde T, Pape HC. Voltage-activated intracellular calcium transients in thalamic relay cells and interneurons. Neuroreport. 1997; 8:2411-2418. [PubMed: 9261800]

61. Noebels JL, Sidman RL. Inherited epilepsy: spike-wave and focal motor seizures in the mutant mouse tottering. Science. 1979; 204:1334-1336. [PubMed: 572084]

62. Oliet SH, Malenka RC, Nicoll RA. Two distinct forms of long-term depression coexist in CA1 hippocampal pyramidal cells. Neuron. 1997; 18:969-982. [PubMed: 9208864]

63. Perez-Reyes E. Molecular physiology of low-voltage-activated T-type calcium channels. Physiol Rev. 2003; 83:117-161. [PubMed: 12506128]

64. Pietrobon D. Calcium channels and channelopathies of the central nervous system. Mol Neurobiol. 2002; 25:31-50. [PubMed: 11890456]

65. Pietrobon D, Striessnig J. Neurobiology of migraine. Nature Reviews Neuroscience. 2003; 4:386398.

66. Powell KL, Cain SM, Ng C, et al. A Ca 3.2 T-type calcium channel point mutation has splicevariant-specific effects on function and segregates with seizure expression in a polygenic rat model of absence epilepsy. J Neurosci. 2009; 29:371-380. [PubMed: 19144837]

67. Richards KS, Swensen AM, Lipscombe D, et al. Novel CaV2.1 clone replicates many properties of Purkinje cell Cav2.1 current. Eur J Neurosci. 2007; 26:2950-2961. [PubMed: 18001290]

68. Rousset M, Cens T, Restituito S, et al. Functional roles of $\gamma 2, \gamma 3$, and $\gamma 4$, three new $\mathrm{Ca}^{2+}$ channel subunits, in P/Q-type $\mathrm{Ca}^{2+}$ channel expressed in Xenopus oocyte. J Physiol (Lond). 2001; 532:583-593. [PubMed: 11313431]

69. Sander T. The genetics of idiopathic generalized epilepsy: implications for the understanding of its aetiology. Mol Med Today. 1996; 2:173-180. [PubMed: 8796880]

70. Singh B, Monteil A, Bidaud I, et al. Mutational analysis of CACNA1G in idiopathic generalized epilepsy. Hum Mutat. 2007; 28:524-525. [PubMed: 17397049] 
71. Song I, Kim D, Choi S, et al. Role of the $\alpha 1 \mathrm{G}$ T-type calcium channel in spontaneous absence seizures in mutant mice. J Neurosci. 2004; 24:5249-5257. [PubMed: 15175395]

72. Splawski I, Yoo DS, Stotz SC, et al. CACNA1H mutations in autism spectrum disorders. J Biol Chem. 2006; 281:22085-22091. [PubMed: 16754686]

73. Stuart, G.; Spruston, N.; Häusser, M. Dendrites. Oxford University Press; Oxford: 2008.

74. Su H, Sochivko D, Becker A, et al. Upregulation of a T-type $\mathrm{Ca}^{2+}$ channel causes a long-lasting modification of neuronal firing mode after status epilepticus. J Neurosci. 2002; 22:3645-3655. [PubMed: 11978840]

75. Talley EM, Solórzano G, Depaulis A, et al. Low-voltage-activated calcium channel subunit expression in a genetic model of absence epilepsy in the rat. Mol Brain Res. 2000; 75:159-165. [PubMed: 10648900]

76. Tan NC, Mulley JC, Berkovic SF. Genetic association studies in epilepsy: "the truth is out there. Epilepsia. 2004; 45:1429-1442. [PubMed: 15509244]

77. Thomas EA, Reid CA, Berkovic SF, et al. Prediction by modeling that epilepsy may be caused by very small functional changes in ion channels. Arch Neurol. 2009; 66:1225-1232. [PubMed: 19822777]

78. Tomita S, Chen L, Kawasaki Y, et al. Functional studies and distribution define a family of transmembrane AMPA receptor regulatory proteins. J Cell Biol. 2003; 161:805-816. [PubMed: 12771129]

79. Tottene A, Conti R, Fabbro A, et al. Enhanced excitatory transmission at cortical synapses as the basis for facilitated spreading depression in CaV2. 1 knockin migraine mice. Neuron. 2009; 61:762-773. [PubMed: 19285472]

80. Trimmer JS, Rhodes KJ. Localization of voltage-gated ion channels in mammalian brain. Annu Rev Physiol. 2004; 66:477-519. [PubMed: 14977411]

81. Tsakiridou E, Bertollini L, de Curtis M, et al. Selective increase in T-type calcium conductance of reticular thalamic neurons in a rat model of absence epilepsy. J Neurosci. 1995; 15:3110-3117. [PubMed: 7722649]

82. Turnbull J, Lohi H, Kearney JA, et al. Sacred disease secrets revealed: the genetics of human epilepsy. Hum Mol Genet. 2005; 14:2491-2500.

83. Umemiya M, Berger AJ. Properties and function of low- and high-voltage-activated $\mathrm{Ca}^{2+}$ channels in hypoglossal motoneurons. J Neurosci. 1994; 14:5652-5660. [PubMed: 8083761]

84. Vadlamudi L, Andermann E, Lombroso CT, et al. Epilepsy in twins: insights from unique historical data of William Lennox. Neurology. 2004; 62:1127-1133. [PubMed: 15079012]

85. Vadlamudi L, Scheffer IE, Berkovic SF. Genetics of temporal lobe epilepsy. J Neurol Neurosurg Psychiatry. 2003; 74:1359-1361. [PubMed: 14570824]

86. Vitko I, Bidaud I, Arias JM, et al. The I-II loop controls plasma membrane expression and gating of $\mathrm{Ca}_{\mathrm{v}} 3.2 \mathrm{~T}$-type $\mathrm{Ca}^{2+}$ channels: a paradigm for Childhood Absence Epilepsy. J Neurosci. 2007; 27:322-330. [PubMed: 17215393]

87. Vitko I, Chen Y, Arias JM, et al. Functional characterization and neuronal modeling of the effects of Childhood Absence Epilepsy variants of CACNA1H, a T-type calcium channel. J Neurosci. 2005; 25:4844-4855. [PubMed: 15888660]

88. Wakamori M, Yamazaki K, Matsunodaira H, et al. Single tottering mutations responsible for the neuropathic phenotype of the P-type calcium channel. J Biol Chem. 1998; 273:34857-34867. [PubMed: 9857013]

89. Wang Y, Rowan MJ, Anwyl R. Induction of LTD in the dentate gyrus in vitro is NMDA receptor independent, but dependent on $\mathrm{Ca}^{2+}$ influx via low-voltage-activated $\mathrm{Ca}^{2+}$ channels and release of $\mathrm{Ca}^{2+}$ from intracellular stores. J Neurophysiol. 1997; 77:812-825. [PubMed: 9065852]

90. Wolfart J, Roeper J. Selective coupling of T-type calcium channels to SK potassium channels prevents intrinsic bursting in dopaminergic midbrain neurons. J Neurosci. 2002; 22:3404-3413. [PubMed: 11978817]

91. Xie G, Clapcote SJ, Nieman BJ, et al. Forward genetic screen of mouse reveals dominant missense mutation in the P/Q-type voltage-dependent calcium channel, CACNA1A. Genes Brain Behav. 2007; 6:717-727. [PubMed: 17376154] 
92. Yaari Y, Yue C, Su H. Recruitment of apical dendritic T-type $\mathrm{Ca}^{2+}$ channels by backpropagating spikes underlies de novo intrinsic bursting in hippocampal epileptogenesis. J Physiol (Lond). 2007; 580:435-450. [PubMed: 17272342]

93. Yang Z-Q, Barrow JC, Shipe WD, et al. Discovery of 1,4-substituted piperidines as potent and selective inhibitors of T-type calcium channels. Journal of Medicinal Chemistry. 2008; 51:64716477. [PubMed: 18817368]

94. Zhang Y, Mori M, Burgess DL, et al. Mutations in high-voltage-activated calcium channel genes stimulate low-voltage-activated currents in mouse thalamic relay neurons. J Neurosci. 2002; 22:6362-6371. [PubMed: 12151514]

95. Zhang Y, Vilaythong AP, Yoshor D, et al. Elevated thalamic low-voltage-activated currents precede the onset of absence epilepsy in the SNAP25-deficient mouse mutant Coloboma. J Neurosci. 2004; 24:5239-5248. [PubMed: 15175394]

96. Zhong XL, Liu JRR, Kyle JW, et al. A profile of alternative RNA splicing and transcript variation of $C A C N A 1 H$, a human T-channel gene candidate for idiopathic generalized epilepsies. Hum Mol Gen. 2006; 15:1497-1512. [PubMed: 16565161]

97. Zhou Q, Godwin DW, O'Malley DM, et al. Visualization of calcium influx through channels that shape the burst and tonic firing modes of thalamic relay cells. J Neurophysiol. 1997; 77:28162825. [PubMed: 9163395]

98. Zwingman TA, Neumann PE, Noebels JL, et al. Rocker is a new variant of the voltage-dependent calcium channel gene Cacnala. J Neurosci. 2001; 21:1169-1178. [PubMed: 11160387] 


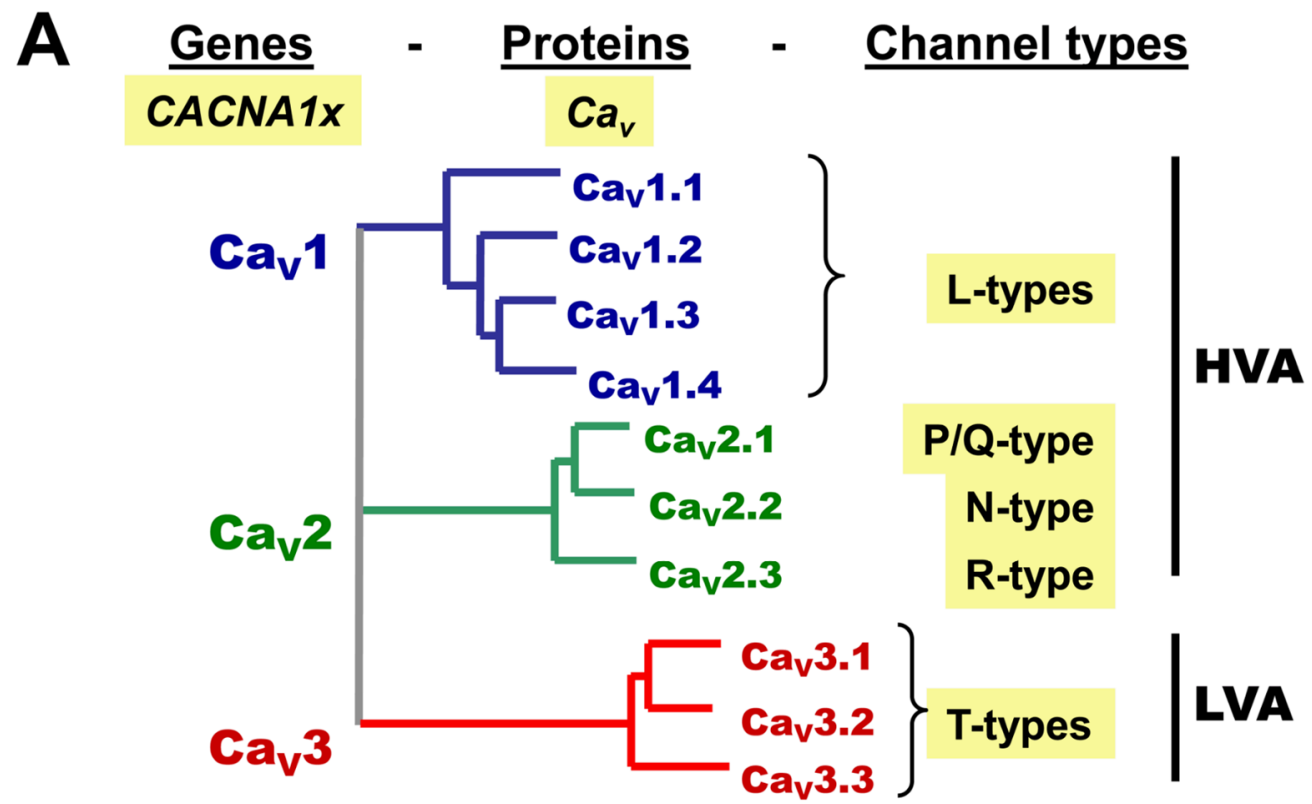

B

HVA :

LVA :

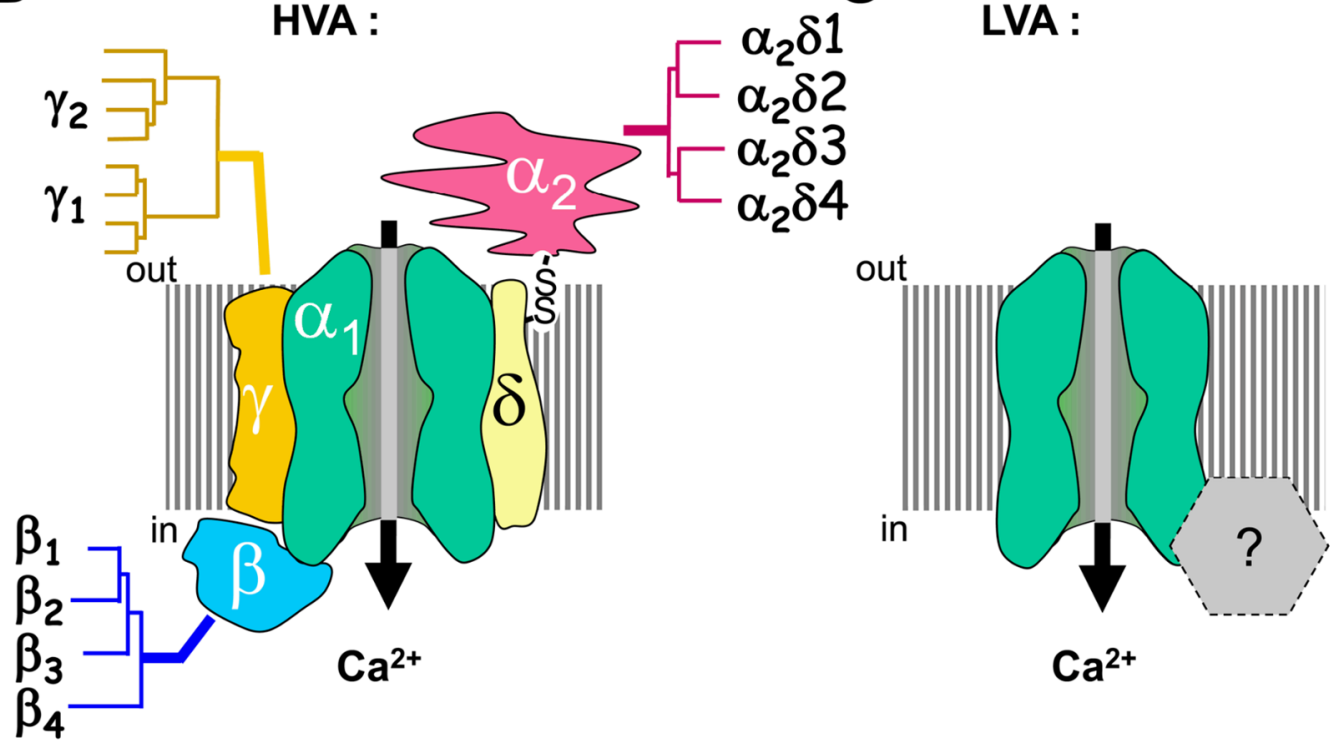

Figure 1. Voltage-gated calcium channels (VGCCs): naming and structure

A. Dendrogram illustrating the three subfamilies of VGCCs: the $\mathrm{Ca}_{\mathrm{v}} 1$ (L-types), the $\mathrm{Ca}_{\mathrm{v}} 2$ (neuronal types), and the $\mathrm{Ca}_{\mathrm{v}} 3$ (T-types). $\mathrm{Ca}_{\mathrm{v}} 1$ and $\mathrm{Ca}_{\mathrm{v}} 2$ channels are high-voltage activated (HVA), in contrast to $\mathrm{Ca}_{\mathrm{v}} 3$ channels (T-types), which are low-voltage activated (LVA). B. The molecular structure of HVA channels comprises ancillary subunits $\alpha_{2} \delta, \beta$, and $\gamma$, each encoded by several subunits. In contrast, the subunit composition of LVA/T-type channels is not yet resolved. 


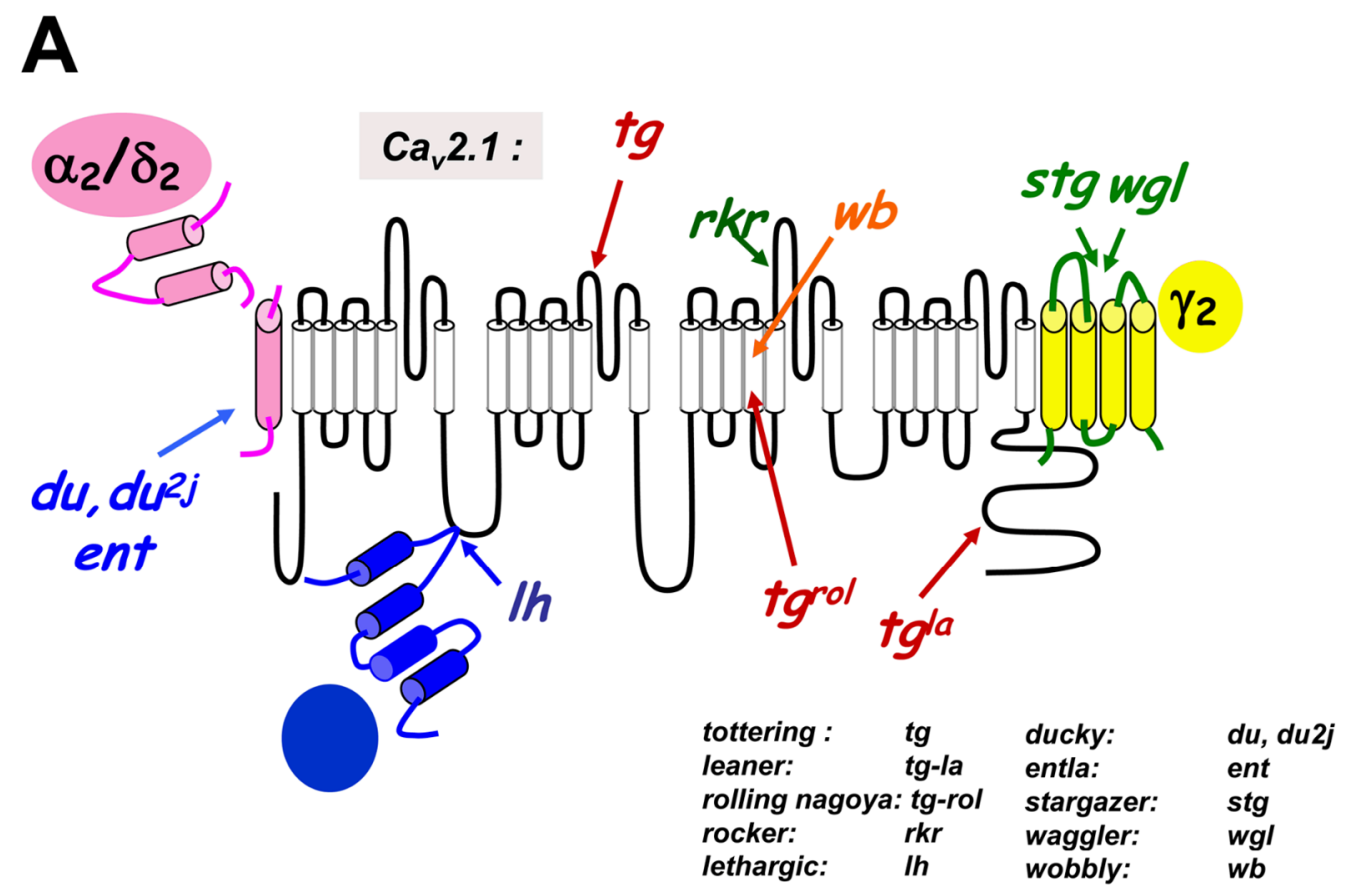

B

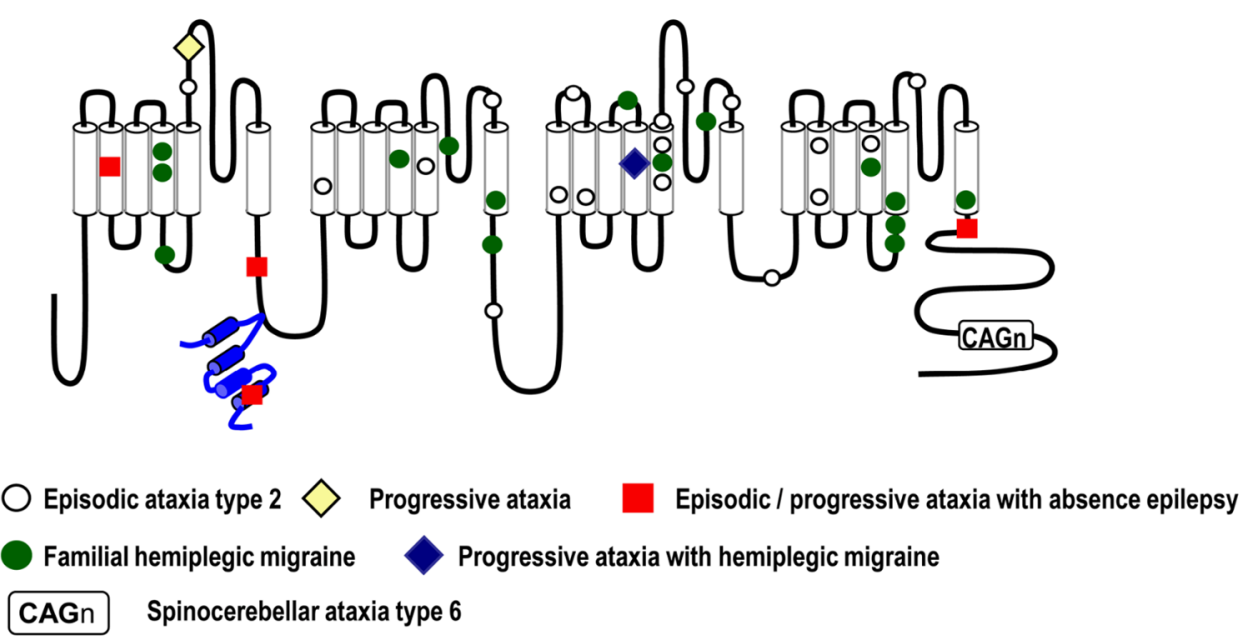

Figure 2. Mutations in $P / Q$-type calcium channels in mouse (A) and humans (B)

A. Schematic representation of the multiple mutations that affect the various subunits of the P/Q-type calcium channels in mouse and the corresponding mouse phenotypes. $\mathbf{b}$ Location of mutations in human P/Q-type $\alpha 1$ subunits that related to episodic ataxia type 2 (EA2), familial hemiplegic migraine type 1 (FHM1), spinocerebellar ataxia type 6 (SCA6), as well as more complex clinical patterns such as progressive ataxia with absence epilepsy (red squares) are indicated. 


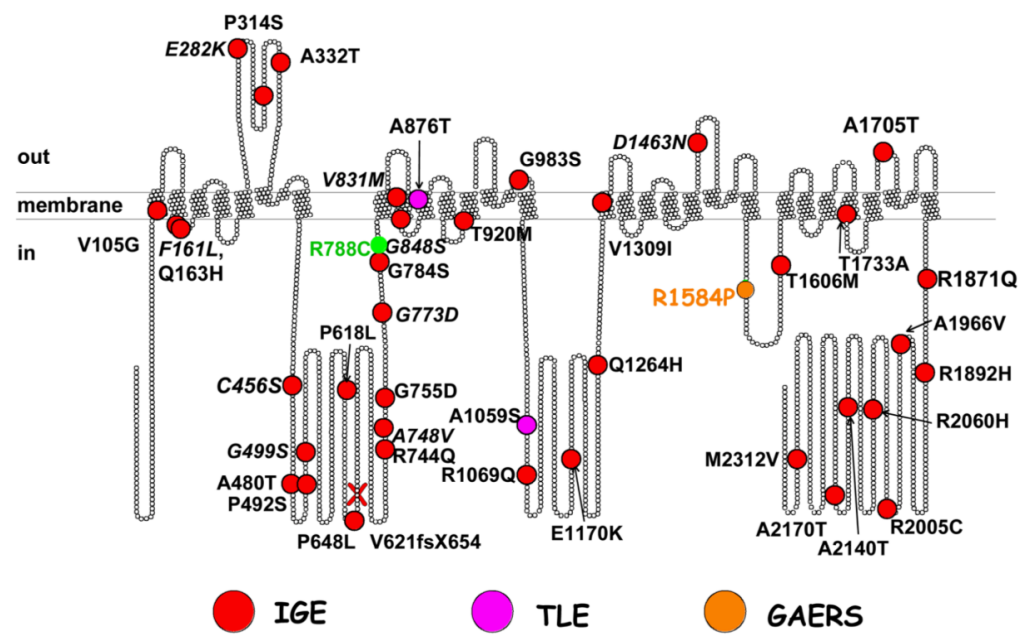

Figure 3. Variants of $\mathrm{Ca}_{\mathrm{v}} 3.2$

Location of IGE variants are mapped on a scaled model of $\mathrm{Ca}_{\mathrm{v}} 3.2$ (each ball represents an amino acid). Key: red balls, IGE variants reported by Chen et al., [21] and Heron et al., [37]; orange ball, the GAERS variant [66]; pink balls, TLE variants [37]; and green, the common SNP, R788C. A frame-shift mutation, V621fsX654, was found in patients with febrile seizures, which leads to premature truncation of the protein at a.a. residue 654 [37]. 